\title{
The auxiliary of the Romanian conditional: semantic and functional arguments concerning the reconstruction of a disputed grammaticalization process
}

\author{
Rodica Zafiu* \\ Faculty of Letters, University of Bucharest, 5-7 Edgar Quinet St., 010017 Bucharest, Romania \\ "Iorgu Iordan - Al. Rosetti" Institute of Linguistics, 13 Calea 13 Septembrie, 050711 Bucharest, Romania
}

\section{Article info}

History:

Received July 12, 2017

Accepted August 16, 2017

Published September 30, 2017

Key words:

historical grammar

diachrony

\begin{abstract}
This paper aims at demonstrating the explanatory advantages of the old hypothesis concerning the origins of the auxiliary of the Romanian analytic conditional $(a s ̧+$ infinitive $)$ as deriving from the imperfect tense form of the verb (a) vrea '(to) want' < *volere (< VELLE). The grammaticalization process, reconstructed through the comparison with the other Romance languages and by relating it to typical directions of the linguistic change, presupposes intermediary semantic phases (the future-in-the-past value, the hypothetical value which is mostly counter-factual), whose traces may be found in the first Romanian (translated) texts, but which have been generally considered a consequence of the simple loan translation from the language source. The uses of the conditional with a reduced auxiliary (aş, ai, etc. + infinitive) are related to those (cooccurring in the old texts) of the conditional with a recognisable auxiliary (vrea 'wanted' + infinitive), for which the value specific to the first grammaticalization stage is still strong - that of a future-in-the past. The text also puts forth an explanation for the atypical forms within the paradigm of the conditional auxiliary-aş(i), ar( $\breve{a})$ - through the overlap between the forms of the imperfect and the simple past of the verb (a) vrea '(to) want'.
\end{abstract}

\section{Introduction}

The origin of the auxiliary used in the formation of the paradigm of the conditional mood in Romanian constitutes the topic of a long standing debate. The main hypotheses are those which presuppose that at the origin of the auxiliary paradigm lies (in various modal-temporal states) (a) the verb HABERE; (b) the verb *volere; besides these, there also exist compromise solutions (e.g., the idea of a contamination between the two paradigms) or stands acknowledging lack of decision. In support of the various explanations, parallelisms with the Romance conditional or connections with other periphrases of the conditional in the old language, with the forms of the conditional in Istro-Romanian and the dialect of Banat have been mentioned. The various theories have sometimes provided additional etymological explanations for the atypical forms aş (1st person singular) and $\operatorname{ar}(3 \mathrm{sg}=3 \mathrm{pl})$, though not sufficiently convincing.

We intend to browse through the main arguments brought forth by the supporters of each of the hypotheses and to reinterpret them by shifting the focus from those explanations based primarily on the evolution of forms to those which take into account the regularities of the grammaticalization process as a whole, with the involvement of the semantic and functional factors. This type of approach favours the hypothesis according to which the auxilary developed from the verb a vrea 'to want', a hypothesis which enjoys the advantage of a tight correlation between the presupposed changes and the semantic and functional peculiarities of the conditional in general and of the Romanian modal-temporal system in particular.

\footnotetext{
*Email address: rodica_zafiu@yahoo.com.
} 
In the earliest available texts, originating from the $16^{\text {th }}$ c., the conditional auxiliary is attested (in anteposition) within the forms: $1 \mathrm{sg} a s ̧ / a s ̧ u / a s ̧ i^{1} ; 2 \operatorname{sg} a i ; 3 \mathrm{sg}=\mathrm{pl}$ ară $/ \operatorname{are}^{2} ; 1 \mathrm{pl}$ am; $2 \mathrm{pl}$ ați. A segmentation problem appears with the forms following the infinitival form of the verb which will be discussed later in the paper: the forms are preceded by the sequence $-r e-$ which could be either the ending of the infinitive or the initial segment of the auxiliary ${ }^{3}$.

The construction seems old and strongly grammaticalized: it exclusively contains the infinitive without $a$ (which indicates its stabilization to be anterior to the association of the preposition $a$ to the infinitive), and the specific forms (aș, ară) never appear by themselves in other combinations, but are specialized for conditional marking. The other forms within the auxiliary paradigm are also functionally specialized (for the collocation with the infinitive and for the conditional value of the periphrasis), even if they enter homonymy relations with other verbal forms: the form $2 \mathrm{sg}$ ai is identical to that of the present indicative of the verb a avea 'to have' and to that of the auxiliary for the compound perfect auxiliary also originating from a avea (for the same grammatical person), the $3 \mathrm{sg}$ variant are is identical to the same person of the present of the verb a avea (to have), and $1 \mathrm{pl}$ am and $2 \mathrm{pl}$ ați are homonymous to the auxiliary for the compound perfect.

The form for the $3 \mathrm{sg}$ is the only one which changes in time, from the time of the first attestations; ară, which is dominant in the $16^{\text {th }}$ c., persists into the $17^{\text {th }}$ c. (in MI 1620, Prav.1652, in SA.1683, în BB.1688, etc.), just like are (Prav.1646, вв.1688, etc.), but the two variants start being replaced by ar, which had previously been occasionally used ${ }^{4}$. Towards the end of the $18^{\text {th }}$ century, the form ar gets generalised. Gheție (1994, p. 28) considers that ar is an innovation that begins from the Southern area and extends into Moldavia and then later into the trans-Carpathian areas, where are and ară have been recorded by dialectal investigations even during the $20^{\text {th }}$ century (see, for instance, Papahagi, 1925, p. LXVIII). The ending of the $1^{\text {st }}$ person sg. varies both in the language during the previous centuries as well as in presentday Romanian, being interpretable as a palatalized pronunciation of the final consonant $s^{5}$ vs. a nonpalatalized one.

\section{The hypotheses concerning the origin of the auxiliary}

The hypothesis regarding its origin from *volere and the one taking HABERE as the source have had numerous supporters in time; the latter has also given rise to many variants depending on the selected modaltemporal paradigms, often combined, through which the forms of the auxiliary have been explained. Among the various supporters of both hypotheses there are some differences concerning the relative chronology of the transformations. Densusianu (1975, p. 572) and Lombard (1954-1955, p. 962-963) have found it preferable not to adopt any of the main theories on the origin of the conditional auxiliary ${ }^{6}$.

\footnotetext{
${ }^{1}$ The form aşu is first attested in PH.1500-10; ași appears in CV.1563-83, occasionally in PO.1582, etc.; aş is the dominant form in P0.1582. Several examples in the texts are reproduced by Densusianu (1975, p. 569). The frequency of the forms may be verified by resorting to the platfom Corpus electronic al textelor româneşti vechi [Electronic corpus of old Romanian texts] [online].

${ }^{2}$ The form ară is very frequent in PH.1500-10, СC ${ }^{2} .1581$, Cт.1560-1, PO.1582, etc. A variant of it, aru, is attested in a document dating from 1593 (Frâncu, 2009, p. 121). In order to identify the forms within the texts, see the indication in the preceding footnote.

${ }^{3}$ The segmentations belong to the editors, all these forms containing a postposed auxiliary being written without a break: vreareas, vreareați, vreareară, etc.

${ }^{4}$ Frâncu (2009, p. 122) considers that the short form ar had not yet appeared during the old period of literary Romanian (until 1640), contesting the authenticity of several previous attestations. Nevertheless, there exist some attestations of ar in the $16^{\text {th }}$ century (e.g., in P0.1582, see Arvinte, 2007, p. 317) and from the first decades of the $17^{\text {th }}$ century (e.g., in A.1620, 16 $)$. The form ar becomes quite recurrent in Prav.1652, but it is still rare in Prav.1646, Bв.1688 (Arvinte, 2004, p. LI), etc.

${ }^{5}$ In the grammar of Diaconovici Loga (1822) there are inconsistencies even in the conjugation tables where both aş and aşi are mentioned (see, for instance, p. 104 and p. 110).

${ }^{6}$ Densusianu's statement is often quoted:"le conditionnel formé avec aşi reste encore une énigme de la morphologie roumaine" [the conditional formed with the aid of aşi still remains a mystery of the Romanian morphology] (1975, p. 572).
} 


\subsection{The HABERE hypothesis}

Those who have argued that at the origin of the conditional auxiliary lies the verb HABERE/a avea 'to have' have started from its present or perfect forms or have assumed a combination of paradigms. The HABERE hypothesis is quite old, with numerous supporters in the $19^{\text {th }}$ century ${ }^{7}$; it was initially accepted by Meyer-Lübke (1895, p. 154), who later adopted (in Meyer-Lübke, 1900) the ideas of Weigand (1896). The explanation was resumed in various variants by Tiktin (1904), Rosetti (1932, p. 104), Titova (1959), Bugeanu (1970), Theodorescu (1978, p. 296-297), Elson (1992), Zamfir (2007, p. 321-376), Popescu (2013, p. 202-204), etc.

The modal-temporal forms considered as a point of departure in the development towards the status of an auxiliary ${ }^{8}$ are the present (Titova, 1959), the pluperfect of the indicative or the imperfect of the subjunctive (Tiktin, 1904), the perfect indicative (Bugeanu, 1970; Elson, 1992) and often a combination of paradigms - the imperfect of the indicative, the imperfect of the subjunctive, the past perfect of the subjunctive, etc. These explanations firstly take into account the form and have no interest in a coherent motivation of the semantic development (from a avea 'to have' with various temporal values to the optative and conditional). The already mentioned points of formal relatedness have influenced the preference for the explanation through HABERE: the coincidence of some forms with the auxiliary in the compund perfect ( $a i, a m, a t i)$, the relatedness and identity with the form of the lexical verb a avea (ar/are). The HABERE theory has also rested on the comparison with Romance, favouring the auxiliary which acted as a source for the forms of the conditional in the other Romance languages. This is, however, a punctual and partial comparison which does not take into account the lack of similarity in the formation of the future. The HABERE hypothesis presupposed clefting of the construction with the postposed auxiliary wherein the main verb would have the long infinitive (fire-ar); Hasdeu (1892, p. 1946) considered that the reanalysis of the sequence of type fire-ar and the different clefting-fi-rear-might have led to the emergence of the auxiliary forms in Istro-Romanian and in the dialect of Banat (with the -re from the long infinitive having become their initial segment): rear $f$, an explanation which is later resumed by numerous supporters of the HABERE hypothesis (Tiktin, 1904, a.o.).

\subsection{The *volere hypothesis}

Even since the end of the $19^{\text {th }}$ century, the conditional auxiliary has been related to the Latin ${ }^{*}$ volere $<$ velle by Philippide (1894, p. 69), who initially considered that the starting point in the development was the subjunctive; the detailed explanation was, however, put forth by Weigand (1896), who demonstrated the origin of the auxiliary in the paradigm of the imperfect indicative of *volere-volebam; the explanation was then adopted by Philippide (1927, p. 203-204) , Meyer-Lübke (1900, p. 356), Morariu (1925, p. 5464), Iordan (1928), Capidan (1932), Ivănescu (2000, p. 163), Minuț (2002, p. 155-157), Arvinte (2004, p. LI-LII), Coene \& Tasmowski (2006), Pamfil \& Dănilă (2009), a.o.

The main arguments in favour of this explanation come from the comparison with Istro-Romanian, with the dialect of Banat and with the periphrases in older stages of Romanian which contain unmodified forms of the verb a vrea 'to want'. The *volere theory also rests on the comparison with Romance, retaining the peculiarity of evincing the same auxiliary for the future and the conditional: HABERE in the Western Romance languages, ${ }^{*}$ volere in Romanian. The current form of the auxiliary would then come as a consequence of the apheresis of the initial consonants of the verb (am < vream, ați < vreați, etc.), and

\footnotetext{
${ }^{7}$ The first supportes of the idea-F. Diez, T. Cipariu, A. Cihac, B. P. Hasdeu, etc.—are mentioned by Philippide (1927, II, p. 202-204).

${ }^{8}$ Some authors opt for the etimology of HABERE without, however, explicitly indicating the mood or the tense out of which the auxiliary might have been formed; this is the state of affairs in Rosetti (1978, p. 565; cf. p. 158, where an option for habuissem $>$ as is, nevertheless, manifested).

${ }^{9}$ Philippide (2011, p. 527-528) claims to have had precedence over Weigand regarding the account of the auxiliary through *volere, and to have been the first to suggest in his 1896 course that the origin of the auxiliary should be traced back to the imperfect paradigm.
} 
probably as a result of a reanalysis. The frequently post-verbal position of the auxiliary in old Romanian allows the reconstruction of a process which probably started from the long infinitive and the auxiliary with the apherised initial $v$-. In fire-(v)reați a haplology would thus have taken place through the dropping of the reiterated syllable re. Arvinte (2004, p. LI) considers that the syllable fell out of the auxiliary-so that the auxiliary retains the same form with anteposition or postposition, and the postposed infinitive is long; fire, in fire-ați. One may assert-as Weigand (1896) did, followed by Meyer-Lübke (1900, p. 356), Morariu (1925, p. 57) — that the syllable has got astray from the form in the infinitive, so that the auxiliary is in its inversion form nearer to the origin (reaț), and the anteposed infinitive is identical to the postposed one, that is, short: $f i$, in $f$-reaț $i^{10}$.

Irrespective of how the simplification of the repeated syllable in older sequences of the language might have occurred, it is possible that the sequence of type $f$-reați (verb-auxiliary), used alongside reațifi (auxiliary-verb), might have been reinterpreted as including the long infinitive (during a period of time when it was still employed as a variation to the abbreviated form). The new segmentation fire-ați could have influenced the anteposed form of the auxiliary, thus producing or at least accelerating the shortening process for ați. The forms of the auxiliary could thus be the result of an apheresis (of the initial consonant $v-)$, but also of a reanalysis of the sequence with postposition. This hypothesis represents the perfect symmetric overthrow of the quite well-spread idea (v. supra, \$2.1) that the initial form fire-ați would have been reanalysed as $f$-reați, giving rise to the variants of the auxiliary in Istro-Romanian and in the dialect of Banat.

\subsection{The mixed paradigm hypothesis}

A combination between the forms of the two auxiliaries has also been advanced by several authors (mentioned by Elson, 1992, p. 363). Frâncu (2009, p. 121-122) considers that an overlap between paradigms took place so that the auxiliary originates from the imperfect of *volere in the case of the $3 \mathrm{sg}$ and $3 \mathrm{pl}$ persons, from the present of HABERE in what concerns the $2 \mathrm{sg}, 1 \mathrm{pl}, 2 \mathrm{pl}$ persons and from the imperfect of *volere or that of HABERE when it comes to the 1 sg person. Again, the explanation is only determined by the possibility of some phonological development, with no semantic justification regarding the process of grammaticalization of the auxiliary with respect to such blending of verbs and tenses.

\section{Semantic arguments and characteristics of the grammaticalization path}

An important argument for the *volere theory is supplied by the grammaticalization model of the conditional in relation to the future. As Fleischman (1982) showed, the conditional in Romance started as a future-in-the-past. The two periphrases-of the simple future and of the future-in-the-past-have grammaticalized at the same time (although there exist discussions about the possible precedence of one over the other form) and in obvious interrelation, having an auxiliary developing from the same verb ${ }^{11}$.

\subsection{The future and the conditional}

If we accept the *volere hypothesis, from a typological perspective, Romanian ranges with languages which use the same auxiliary and the same morpho-syntactic pattern for the future and the conditional ("VELLE serves both for the future and the conditional”, Iordan, 1928, p. 197) and which derive the conditional from the future-in-the-past ${ }^{12}$. It is the dominant model in Romance, but it is quite well-spread in other languages from various families as well; one of the most studied cases (and the most interesting for a comparison with Romanian) is that of the modal will in English, whose present form is used for the

\footnotetext{
${ }^{10}$ Philippide $(1894,1927)$ considers that the Daco-Romanian inversion uses the long infinitive, but he marks the short infinitive in the examples from Istro-Romanian: vol'i-ręs 'I would want'.

${ }^{11}$ For more recent approaches to the diachrony of the conditional in Romance, see Parkinson (2009), Vincent (2013), Esher (2013).

${ }^{12}$ Punctual comparisons have been made within the Romance area: the imperfect of *volere seems to have been employed in the dialect of Matera (Iordan, 1928, p. 197).
} 
future, and whose etymological past form (would) becomes the auxiliary of the conditional (Bybee, 1995; Iatridou, 2000, etc.).

In $16^{\text {th }}$ century Romanian, both the future of the type voi face, and the conditional of the type as face were completely grammaticalized. The high frequency of the future construction voi face ('I will do', with the verb 'will/want'), the infinitive without $a$ and its (exclusively) temporal sense indicate it to be older than other periphrases for the future (more rare, built with the aid of the $a$-infinitive or with the subjunctive, and having - in the case of the periphrases with a avea 'to have'-, rather a modal meaning of necessity than a temporal one). The periphrasis voi infinitive represents at the time the prototypical future; this is why it is quite probable that a future in the past taking it as basis (by switching the auxiliary from the present to the past) might have triggered the development towards the conditional value. The periphrasis of the type va face 'will do' (present + infinitive) enabled the development of a periphrasis vrea face 'would do' (imperfect + infinitive), just as are să facă 'has to do' will give birth to the future-in-the-past avea să facă 'had to do' (Zafiu, 2013, p. 40; Popescu, 2014).

The future with a avea 'to have' undergoes grammaticalization at a later stage, and it does so incompletely; the construction of the verb a avea with the $a$-infinitive (are a $f$ ' has to be') is rather rare in the $16^{\text {th }}$ century, and only has a modal value, that of necessity (Călăraşu, 1987, p. 187; Zamfir, 2007, p. 232-241).

The meanings which the construction aş + infinitive develops diachronically-of posteriority in the past and of possibility/hypothetical meaning-also count as an argument in favour of the *volere hypothesis. Titova (1959) supported the HABERE hypothesis by observing that aş + infinitive in the old texts had a meaning that would be nearer to the future than to the conditional, which seems to indicate a transformation of the construction-from a modal value of necessity ('has to do') to a future value first and then to a conditional one. The relatedness of the values of the future and the conditional and even the common contexts of occurrence (in the conditional construction) do not, however, presuppose equivalence and overlapping. There are no precedents to justify the simple diachronic transformation of a future into a conditional; on the other hand, the association of morphological markers for future with those for the past represents the typical source of a mood of the hypothetical condition-the conditional (James, 1982; Bybee, 1995; Iatridou, 2000).

In the analysis of old Romanian texts the value of the present or past conditional was established by the researcher in a rather arbitrary way, often through the mere replacement possibility with the current forms. For a better understanding of the values of the periphrases under discussion, we start from the observations in Iatridou (2000): the conditional is either counterfactual or non-counterfactual, the counterfactual interpretation being an implicature. The perfect conditional is counterfactual; the present conditional may be conterfactual but it is not necessarily so, depending on the meaning of the verbs and the context. Counterfactuality as a semantic feature does not thus overlap with the morphological opposition between the perfect and the present conditional.

The transformations which interest us and which lead to the fixing of certain modal values of a modaltemporal periphrasis have been preceded by the grammaticalization of the modal-temporal periphrasis starting from a free combination of words, having a modal value ${ }^{13}$. It is natural to presuppose (also by comparing developments in other languages) that the periphrasis *volere + infinitive initially expressed will, intention, from where the switch to expressing posteriority is easily reached (Bybee et al., 1994, p. 243-279; Heine \& Kuteva, 2002, p. 310-311). The future, through its semantic component of not (yet) actualised facts still continues to have double and ambiguous status, with the open possibility of considering it both as a mood as well as a tense ${ }^{14}$.

The future periphrasis ( $v a+$ infinitive) could be used (through the modification of the tense auxiliary) as future in the past (vrea + infinitive):

\footnotetext{
${ }^{13}$ Azzopardi (2013) describes this first phase in the grammaticalization of the conditional in Spanish.

${ }^{14}$ For a recent overview of the debate on the modal and/or temporal nature of the future, see Giannakidou \& Mari (2017).
} 
voiface (intention) $\rightarrow$ voiface (future)

(I) will do 'I want to do' $\rightarrow$ (I) will do

vrea $(s)^{15}$ face (intention in the past) $\rightarrow$ vrea $(s)$ face (future in the past)

(I) would do 'I wanted to do' $\quad \rightarrow \quad$ (I) would do 'I was about to do'

The periphrasis for the future in the past, which has the characteristic to morphologically mark both the past as well as the future, constitutes the typical source for the (counterfactual) hypothesis in many languages, in the conditional construction and in desirative sentences (Iatridou, 2000). The hypothetical value extends afterwards to the present in sentences which can be counterfactual as well as noncounterfactual. With the rise of a specialised construction for the counterfactual hypothesis referring to the past (past conditional), the first form of the conditional restricts its meaning turning into a present conditional.

Hence, a periphrasis of the type vrea(s) face '(I)would do' undergoes the following path of semantic change in time:

(I) 'I had to do' (future in the past) $\rightarrow$ (II) 'I would have done' (hypothetical-counterfactual) $\rightarrow$ (III) 'I would do' (hypothetical-counterfactual or non-counterfactual)

In the second stage, the periphrasis may be equivalent both with a past conditional and with a present conditional with a counterfactual interpretation. In the third stage, its value as a present conditional becomes fixed. The temporal value from the first stage may persist in certain contexts.

Such a change regarding the specific value of the Romanian conditional has been proposed by Ivănescu (2000), by analogy with the developments in other Romance languages, in Greek, etc.: "The initial meaning of the Western Romance form, which currently functions as unreal present, was that of unreal past. This «I would have sung» meaning must have been also held by the Romanian present irrealis" (p. 163).

\subsection{Traces of the grammaticalization process in the old texts}

In order to verify the grammaticalization path described above, one needs to establish first whether in the old texts the periphrasis ar + infinitive had a temporal value of future in the past or not. In spite of what has been often claimed (Coene \& Tasmowski, 2006; Zamfir, 2007, etc.), the value of the future in the past (posteriority in the past) seems to have persisted in the $16^{\text {th }}$ century, with the periphrasis subordinated to a declarative verb in the past (1) or in a narrative context, competing with the simple past (2):

(1) $\mathrm{Ei}$ se împlură de nebunii și grăiră

they CL.REFL.ACC.3PL fill.PS.3PL of madness.PL and speak.PS.3PL

unul la alalt ce ară $f i$ să se

one to another what AUX.3SG be S $\breve{A}_{\text {SUBJ }}$ CL.REFL.ACC.3SG

facă lu Isus. (Ст.1560-1, 125 $)[L k, 6,11]$

do.sUBJ.3SG LUI.DAT Jesus

'And they were filled with madness; and communed one with another what they should do to Jesus'

\footnotetext{
${ }^{15}$ The $1^{\text {st }}$ person form vrea is attested in the $16^{\text {th }}$ century as the auxiliary of the conditional; vreaş is a reconstruction starting from the current forms aş (Daco-Romanian) and reaş / ręš (the dialect of Banat, Istro-Romanian).

${ }^{\ddagger}$ Abbreviations used in glosses: 1 - first person; 2 - second person; 3 - third person; $A_{\mathrm{INF}}$ - marker of infinitive; ACC accusative; AUX - auxiliary of the future in the past and of the conditional; AUX.PERF - auxiliary of the composed past; CL pronominal clitic; DAT - dative; DEF - definite article; DOM - differential object marker; F - feminine; GEN - genitive; GER - gerund / gerundive; IMPERF - imperfect; INF - infinitive; LUI - proclitic marker of genitive and dative; $M$ - masculine; PASS - passive; PERF - perfect; PL - plural; PPLE - participle; PRES - present (tense); REFL - reflexive; S $\breve{A}_{\text {SUBJ }}$ - marker of subjunctive; SG - singular; SUBJ - subjunctive.
} 
(2) Cest bărbat prinsu e de jidovi și ară vrea ei this man captured is by Jews and AUX.3PL want.INF they să-l ucigă; și apropiiai-mă, $\quad c u$ S $\breve{A U B J}_{\text {SUJ }}=$ CL.ACC.3SG.M kill.sUBJ.3PL and come.close.PS=CL.REFL.ACC.1sG with voinicii luai el: ştiui că rimleanin iaste soldiers.DEF take.Ps.1sG him know.Ps.1sG that Roman is (CPr.1566, 115) [Acts, 23, 27]

'This man was captured by the Jews, and they should kill him: then came I with an army, and rescued him, having understood that he was a Roman'

One can bring into discussion the 'aberrant' examples in P0.1582, signalled by Densusianu (1975, p. 572; cf. Zamfir, 2007, p. 326), where the conditional is a narrative tense with a perfect value. It is very probable that this is a linguistic loan translation from Hungarian, as it has been argued, but this indicates the persistence of a certain temporal value of the periphrasis, which makes it compatible with the contexts of the past:

(3) Și fu lumină. Și vădzu Domnedzeu c-ară $f i$ and be.ps light and see.Ps God that $=$ AUX.3sg be.INF

bună lumina $\quad($ PO.1582, 19) $[$ Gen $, 1,3-4]$

good light.DEF

'And there was light. And God saw that the light was good'

(4) aduse iale la Adam cum să vadză cum

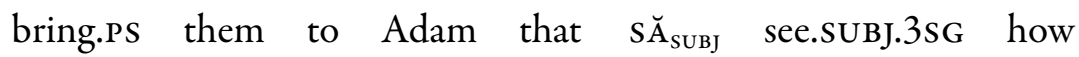

ară chema iale $($ Po.1582, 22) $[$ Gen, 2, 19]

AUX.3sg call.INF them

'He brought them unto Adam to see what he would call them'

This narrative usage also appears in other old texts, generally associated with posteriority in the past; the biblical sequence in (5-6) is generally translated by means of past tenses (in the Greek original the first is an aorist, the second an imperfect $)^{16}$; the imperfect in NT.1648 and BB.1688 corresponds to the conditional in Ст.1560-1:

(5) Și ciți se-ară atinge de el and as.many CL.REFL.ACC.3PL $=\mathrm{AUX} .3 \mathrm{PL}$ touch.INF of him vindeca-se-ară $\quad($ CT.1560-1, 82 $)[M k, 6,56]$

heal.INF $=$ CL.REFL.PASS.ACC.3PL $=$ AUX.3PL

'And as many as touched him were healed'

(6) Și cîți să atingea de el and as.many CL.REFL.ACC.3PL touch.IMPERF.3PL of him să vindeca (NT.1648, 49 $9^{\mathrm{r}}$; Bв.1688, 779) $[M k, 6,56]$

CL.REFL.PASS.ACC.3PL heal.IMPERF.3PL

'And as many as touched him were healed'

At a later stage, the temporal value disappears so that it was asserted that the Romanian conditional is a true mood, illustrating the Eastern conditional (Thieroff, 2010), and not primarily a tense which also develops modal values (an opinion which has often been advanced regarding the French conditional). The lack of temporal value (of a future in the past) in present-day Romanian has been explained through the absence of the SOT ('sequence of tenses') parametric option (D'Hulst et al., 2004). The negative specification of

\footnotetext{
${ }^{16}$ Cf. http://biblehub.com/interlinear/mark/6-56.htm.
} 
the SOT parameter actually explains why the temporal value, which must have existed in the first stage of the grammaticalization of the periphrasis, disappeared.

The value derived from that of posteriority in the past is that of possibility, hypothesis ${ }^{17}$. One would suppose that in an intermediary stage of the grammaticalization process, the periphrasis referred to past deeds (as long as the auxiliary was perceived as temporally marked), with counterfactual implicatures. The $16^{\text {th }}$ century texts do not seem to contain any uses of the periphrasis as face which would illustrate this particular value (equivalent to a past conditional); the value is however occasionally realised as vrea face (v. infra).

The values of the present conditional illustrating the final stage of the grammaticalization process are already present in the $16^{\text {th }}$ century texts, being visible in the conditional construction (in the presence of the specific conjunctions să or $d e$ 'if') as hypothesis (7), as an attenuator in other types of sentences (8) or as a marker of possibility (9):

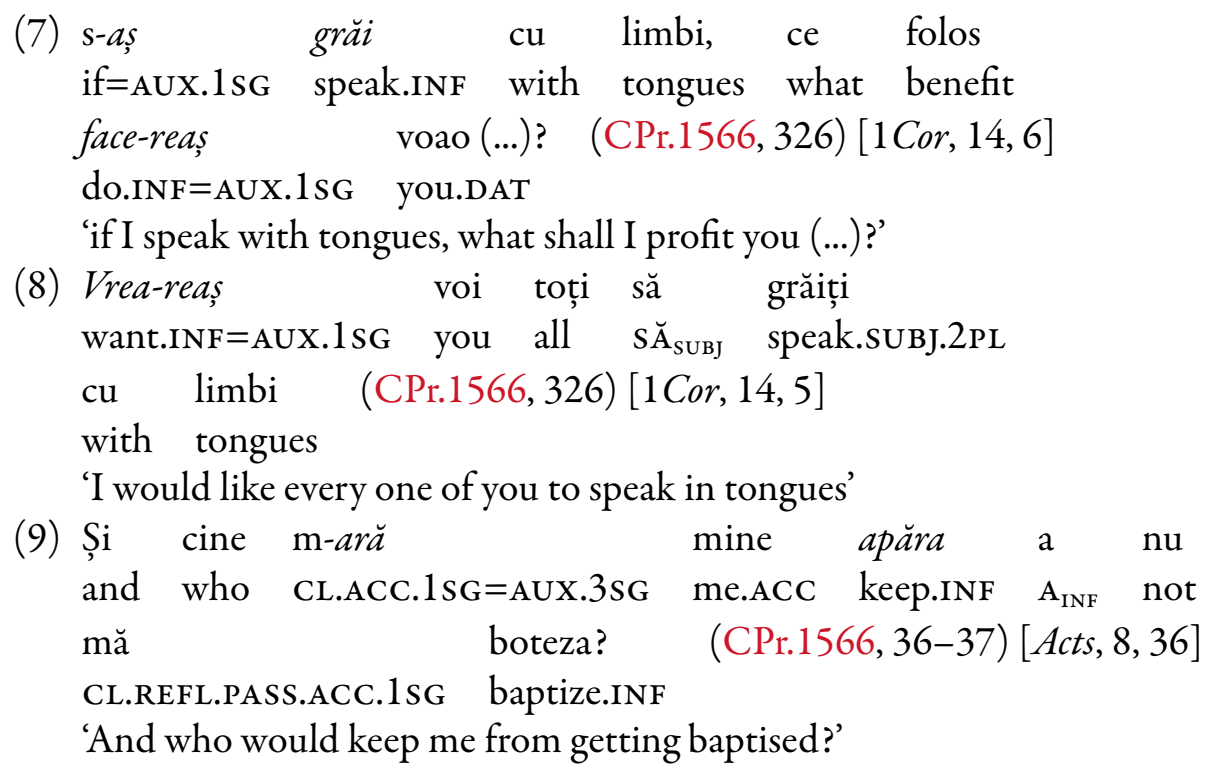

The counterfactual value is contextually acquired, but already stabilised in unreal comparisons:

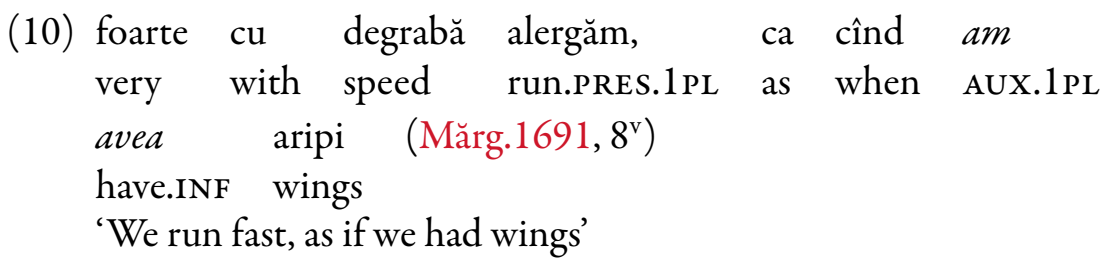

The periphrasis aş + infinitive (no longer) has the value of a perfect conditional in the $16^{\text {th }}$ century, because this value is rendered through the periphrasis of the verb to be and the participle-as fi facut 'I would have done'. As Iatridou (2000) shows, the perfective marker imposes the temporal interpretation of a verbal construction and the doubly marked temporality may distribute thus ensuring the interpretation of counterfactual in the past ${ }^{18}$. One of the markers (ass) functions modally, and the other (the participle)temporally.

\footnotetext{
${ }^{17}$ In opposition to Fleischman (1982) and to the dominating opinion, Bybee (1995) considers that the irrealis value must not be derived from that of future in the past, but that it is simply an effect of the association of a modal form with the past. A construction of the type voiam să plec 'I wanted to leave' would leave open the possibility that the action have been accomplished or not, and the possibility that a previous desire be still valid in the present; hence the meaning of present conditional.

${ }^{18}$ Thus, "when the aspectual part of the verb is perfective, the past morpheme becomes real; that is, it receives a past tense interpretation and it talks about an event of the past” (Iatridou, 2000, p. 237). Cf. James (1982, p. 401).
} 
The periphrasis with a perfect value is already very well represented in the $16^{\text {th }}$ century texts, which may attest its age. The temporal-aspectual model characteristic to Romanian in the $16^{\text {th }}-17^{\text {th }}$ centuries(a) basic form; (b) progressive periphrasis with a $f i$ 'to be' + gerund; (c) perfective periphrasis with a $f i+$ participle (Frâncu, 1983-1984; Zafiu, 2016, p. 32)-presupposes a distribution of the temporal and aspectual values. The basic periphrasis_ară putea (11), ară trebui (13) and the periphrasis with the gerund-ara fi find $(11,12)$-have the value of a present conditional ${ }^{19}$; the periphrasis with the participle-ară fi pus 'would have put' (12); ară fipostit, arăfiținut 'would have held' (13) have the value of a past conditional (counterfactual):

(11) De n-ară $f i$ acesta find de la Dumnezeu, n-ară

if not $=$ AUX.3sG be.INF this be.Ger from God not $=$ AUX.3sG

putea face nemică $\left(\mathrm{CC}^{2} .1581,166\right)[\mathrm{Jn}, 9,33]$

can.INF do.INF nothing

'If this (man) were not from God, he could do nothing.'

(12) Că de-ară fi pus avuțiia bogații

because if=AUX.3PL be.INF put.PPLE wealth.DEF rich.people.DEF

depreună, n-ară $f i$ mișeii în nevoie

together not $=\mathrm{AUX} .3 \mathrm{PL}$ be.INF poor.people.DEF in poverty

fiind nici dinioară $\left(\mathrm{CC}^{2} .1581,36\right)$

be.Ger never

'Because if the rich people had put their goods together, poor people would never be poor.'

(13) Și de-ară fi postit ei, și de-ară fi tinut

and if $=$ AUX.3PL be.INF fast.PPLE they and if $=A U X .3 P L$ be.INF retain.PPLE

să nu mănînce, acmu n-ară trebui noao

SĂ $\breve{s U B J}_{\text {Sot }}$ eat.SUBJ.3PL now not=AUX.3SG need.INF us.DAT

a posti; ce derepce $n$-au postit ei atunce, noi

$\mathrm{A}_{\mathrm{INF}}$ fast.INF but since not=have fasted they then we

toțe-am fost căzuți den dulceața raiului $\left(\mathrm{CC}^{2} .1581,46\right)$

all=have been fall.pple from goodness.DEF Heaven.DEF.GEN

'And if they had fasted, and if they had refrained themselves from eating, we would not need to fast now; but since they did not fast then, we all fell from the goodness of the Heaven'

In the examples above, the asymmetric distribution of the periphrases for the conditional simply reflect the semantic necessities of the text. In protasis it refers to the present or to the past and in apodosis it refers to the present or to the future.

\section{The competing periphrases}

In the $16^{\text {th }}$ century texts there are several periphrases whose conditional value is built with the aid of the auxiliary a vrea 'to will/want' in an identical form with that of the predicative verb; many of them circulate during the next centuries, some of them being retained at a regional level (Frâncu, 2009, p. 122-123, 317318). The constructions built by means of an auxiliary and the infinitive are two, one with the auxiliary in the imperfect (vrea face 'I would do') and the other one with the auxiliary in the compound past (am vrut

\footnotetext{
${ }^{19}$ The perpetuated characterization in the linguistic studies (Densusianu, 1975, p. 570-571; Rosetti, 1978, p. 565, etc.) of the periphrasis with the gerund as having a perfect value finds no justification in the texts or in the temporal-aspectual system of old Romanian. Zamfir (2007, p. 339-349) accurately describes the contexts in which the construction with the gerund appears, but she resorts to many interpretive artifices in order to confirm the hypothesis of its value as a perfect. Arvinte (2007, p. 318) describes the narrative uses of the periphrasis of the conditional with the gerund in P0.1582, perfectly similar to that of the periphrasis of the present conditional. Cf. also Călărașu (1987, p. 231-234).
} 
face 'I would do' $)^{20}$; the main progressive construction is made up of the imperfect of the verb a vrea, the infinitive of $a$ fi 'to be' and the gerund of the lexical verb (vrea fi fäcînd 'I would be doing'). According to the temporal-aspectual system in the old language, the picture is completed with constructions with the past of the verb a vrea, the infinitive of a $f i$ and the participle of the lexical verb-vrea fifacut, am vrut $f i$ făcut 'I would have done' (Densusianu, 1975, p. 571)—which structurally and semantically correspond to the past conditional of the type as f f făcut 'I would have done'; the constructions above may give rise to some doubly-compound forms, used rather rarely.

\subsection{Controversies}

The existence of periphrases with the imperfect of $a$ avea has been considered both an argument in favour of the *volere hypothesis (proving that a variant of the auxiliary enters the formation of a conditional), and an argument against the same hypothesis. On the one hand, it has been argued that it was strange that only forms which illustrate the initial and the final stage of a grammaticalization process resisted and circulated simultaneously, but not those characteristic to its intermediary stages (Tiktin, 1904; Titova, 1959). On the other hand, it was claimed that the periphrasis only had a past value (an unaccomplished possibility in the past), while the present conditional with aş has a present or a future value (a possibility that can be realised in the present or in the future or not).

Both objections can be discarded.

(a) The periphrasis vrea + infinitive may be a case of reconstruction with the same elements, as it sometimes happens in the history of Romanian, even in the case of the verb a vrea (veri 'you will/want' circulates simultaneously with ori, vare 'he will/wants' with oare, and the parallel forms are attested for quite a long time ${ }^{21}$ ). The idea was put forth by Philippide (1894), who considered it as a case of repetition of a pattern - "it is as if the language would have wanted to repeat the old process" (p. 69); cf. Ivănescu (2000, p. 355). On the other hand, it would not be impossible that the periphrasis vrea + infinitive be a mere residue, a variant with certain morphological peculiarities, kept on a par with the grammaticalization of the reduced form. If, as we will argue in the following sections (infra, \$6), aş comes from a hybrid paradigm of a vrea, related to the simple past of the auxiliary, the simultaneous existence of the periphrases using the regular paradigm of the imperfect is all the more possible.

(b) In most cases, the periphrasis vrea + infinitive has the value of a present conditional. The quite well spread view according to which its main value is that of a past conditional (Densusianu, 1975, p. 571; Rosetti, 1978, p. 565; Frâncu, 2009, p. 123; Zamfir, 2007, p. 346) comes from the union of two different uses of the periphrasis in the language during the previous centuries-that of future in the past and of present conditional-but also from those cases where this seems to be equivalent to the perfect. From this point of view, the pattern vrea face evinces an obvious similarity with the pattern ar face: the difference consists in the fact that ar face, which gets grammaticalized at an earlier stage, has fewer uses as a future in the past, while vrea face has numerous uses of future in the past and still retains some of the uses of the counterfactual (past) conditional.

\subsection{The periphrases vrea + infinitive; vrea + infinitive of $\boldsymbol{f}+$ participle}

The periphrasis containing the auxiliary a vrea in the imperfect and the lexical verb in the infinitive (vrea face 'would do') primarily has a future in the past value (the initial value of the Romance conditional and the one deductible from the form by way of transposing the future auxiliary into a past tense). This value frequently gets actualised in contexts in which the narrative tense is the perfect (in aspectual combination with the imperfect):

\footnotetext{
${ }^{20}$ See Densusianu (1975, p. 571), Zamfir (2007, p. 346-355). The second periphrasis uses a compound form as an auxiliary which has its own auxiliary (which indicates a high degree of grammaticalization of the compound perfect).

${ }^{21}$ Other phenomena of recursivity through the reconstruction of the basic form are domnia ta 'you', literally 'your lordship' in relation to the pronoun of politeness dumneata 'you', and maybe nu știu ce 'I don't know what' in relation to the indefinite adjective nişte 'some’.
} 
(14) zise aşa, că şi adoara se

vrea say.PS.3sG so because too a.second.time CL.REFL.ACC.3SG

intoarce într-însul, că încă nu era come.back.INF inside $=$ him because yet not be.IMPERF.3SG

AUX.3SG

nici era îngrădit cu credință. $\quad\left(\mathrm{CC}^{2} .1581,82\right)$

nor be.IMPERF.3SG hedged with faith

'he said so, because he would come back into him, because he was not yet strengthened, or hedged by the faith'

(15) În casă feciorul zăcînd era, in house boy.DEF lying be.IMPERF.3sG neither know.IMPERF.3sG acesta pre Hristos, cine iaste, nici dinioară. this.one DOM Christ who is never Cum vrea putea întru cela ce nu-l how AUX.3SG can.INF in that.one that not=CL.ACC.M.3sG știia să crează? $\quad\left(\mathrm{CC}^{2} .1581,268-9\right)$

knOw.IMPERF.3SG SA $\breve{S U B J}_{\text {S }}$ believe.SUBJ.3SG

'The boy was lying in the house and he did not know at all who Christ was. How would he be able to believe in the one he did not know?'

(16) au

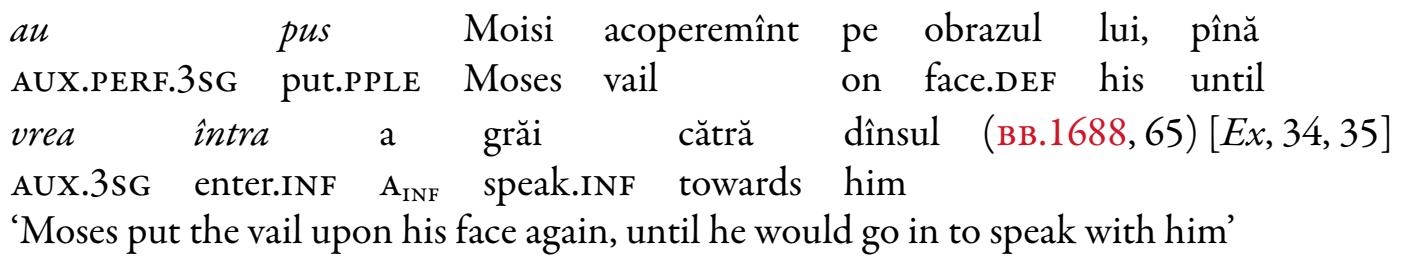

(17) întru locul unde vrea sta norul, acoló in place.DEF where AUX.3SG settle.INF cloud.DEF there tăbărîia fiii lui Israil (B B.1688, 102) [Num, 9, 17] camp.IMPERF.3PL sons.DEF LUI.GEN Israel 'in the place where the cloud settled, there the children of Israel would camp'

In the examples above, the periphrasis may be equated to the current forms of the future in the past (avea să se intoarcă 'would come back/return', avea să poată 'would be able to', avea să intre 'would enter', avea să stea 'would settle'); paraphrasing through the perfect conditional s-ar f întors 'would have returned' is possible in example (15), in the hypothetical context of a question.

The examples in which the periphrasis is equivalent to the past conditional, which are extensively discussed by Zamfir (2007,p. 346-349), seem to activate the temporal value (of imperfect) of the auxiliary, which allows the rendition of the counterfactual hypothesis with reference to the past; the examples thus illustrate an intermediary grammaticalization stage which had already been superseded by the pattern aş + infinitive (see supra):

(18) nu vrea fi zis, de nu le vrea not AUX.3PL be.INF say.PPLE if not CL.ACC.3PL AUX.3sG

părea că iaste adeverit Dumnezeu. ( $\left.\mathrm{CC}^{2} .1581,475\right)$ seem.INF that is true God 'they would not have said this, if it had not seemed to them that he was a true God'

The value of present conditional (conditioned possibility, generic hypothesis or hypothesis referring to the present) prevails in the texts ${ }^{22}$ :

\footnotetext{
${ }^{22}$ Philippide (1888, p. 106) considered that the periphrasis had the value of present conditional.
} 
(19) de-ară fi meseretatea răotatea,

if $=$ AUX.3sG be.INF poverty.DEF malice.DEF

cădea-se-vrea tuturor carii sînt în

be.necessary.INF $=\mathrm{CL} \cdot \mathrm{REFL} \cdot \mathrm{ACC} \cdot 3 \mathrm{SG}=\mathrm{AUX} \cdot 3 \mathrm{sG}$ all.DAT who are in

meserătate răi a fi $\quad\left(\mathrm{CC}^{2} .1581,402\right)$

poverty malicious $\mathrm{A}_{\mathrm{INF}}$ be.INF

'if poverty were malice, all the people who are poor would necessarily be malicious'

(20) Doară cumva spre Dumnezeu luptători

maybe somehow against God fighters

afla-vă-vreați? $\quad(\mathrm{CPr} .1566,22)[$ Acts, 5, 39]

find.INF $=$ CL.REFL.ACC.2PL $=\mathrm{AUX} \cdot 2 \mathrm{PL}$

'You would be found fighting against God'

The periphrasis vrea lăuda 'would praise' persists in the following centuries and is recorded in the grammar of Diaconovici Loga (1822) from Banat. He includes several series of forms in the conjugation tables (which are common for subjunctive and optative); he labels them "present"-aş lăuda 'I would praise', "imperfect"-vream läuda, "perfect"-aş fi lăudat and "pluperfect"-aş fi fost lăudat (p. 96-130). The classification does not necessarily represent a confirmation of the past value of the periphrasis, because it may have been influenced by the tense of the auxiliary. In the $19^{\text {th }}$ century the periphrasis was still attested in all regions and especially in Transylvania (Dragomirescu, 2015, p. 209). Pamfil \& Dănilă (2009) signal the current use of the construction in Crișana and Maramureș-with a present conditional value.

The gradual specialization of the present conditional value also finds an explanation, just as for ar + infinitive, in the existence and systematic use (at least in some texts, such as $\mathrm{CC}^{2} .1581$ ) of periphrases that contain a participle explicitly marking the counterfactual hypothetical in the past:

(21) Că de vrea fi în sîmbătă acesta vindecat, nu vrea since if AUX.3sG be.INF in Saturday this.one heal.pple not AUX.3sG fi tăcut de acesta evanghelistul. $\left(\mathrm{CC}^{2} .1581,267\right)$ be.INF keep.silence.PPLE about this evangelist.DEF

'Had he healed this one in a Saturday, the evangelist would not have kept silence about this'

(22) Că ucenicii, de nu vrea fi știut, doară ei since disciples.DEF if not AUX.3PL be.INF know.PPLE maybe they se vrea fi și săblăznit şi CL.REFL.ACC.3PL AUX.3PL be.INF also worry.PPLE and se vrea fi schimbat. $\quad\left(\mathrm{CC}^{2} .1581,90\right)$ CL.REFL.ACC.3PL AUX.3PL be.INF change.mind.PPLE 'Had the disciples not known (this), maybe they would have worried and would have changed their mind'

Although they were well-represented in the $16^{\text {th }}-17^{\text {th }}$ centuries, the periphrases with a vrea in the imperfect became obsolete; very few regional traces have been retained to the present day. Their disappearance might be related to the fact that they simply doubled the values of the standard paradigms-as face 'would do' and aş fi facut 'would have done'.

\subsection{The periphrasis am vrut + infinitive}

The periphrasis with the verb a vrea in the compound past, although more rarely used, has the values of future in the past and of counterfactual hypothesis referring to the past (that is, of perfect conditional):

(23) Că de-au vrut vrea amu a munci, since if=AUX.PERF.3SG AUX.PPLE want.INF then $A_{\text {INF }}$ torture.INF 
aceasta n-ară $f i \quad$ prorocit $\quad\left(\mathrm{CC}^{2} .1581,414\right)$

this not=AUX.3sG be.INF prophesy.PPLE

'Had he wanted to torture, he would not have prophesied this'

(24) încă n-ai făcut destul cît au vrut

yet not=AUX.PERF.2SG do.PPLE enough how.much AUX.PERF.3SG aux.PPLE

trebui și cît ai vrut putea face $\left(\mathrm{CC}^{1} .1567,313\right)$

need.INF and how.much AUX.PERF.3SG AUX.PPLE can.INF do.INF

'You did not do enough yet what you would have needed and would have been able to do'

(25) Derept aceaia, frații miei, să $\mathrm{n}$-au vrut naște

therefore brothers.DEF my if not=AUX.PERF.3SG AUX.PPLE be.born.INF

Iisus Hristos, noi am vrut toți peri;

Jesus Christ we AUX.PERf.1pl AUX.PPle all perish.INF

ce-au născut derept noi păcătoșii $\left(\mathrm{CC}^{1} .1567,383\right)$

but=AUX.PERF.3SG be.born.PPLE for us sinners.DEF

'Therefore, my brothers, if Jesus Christ had not been born, we would have all perished; but he is born for us, the sinners'

The difference with respect to the imperfect auxiliary-the absence of the value of present conditionalmay arise from perfective marking (through the participle).

\subsection{The periphrasis vrea + să-subjunctive}

From the future built with $v a$ ( $3 \mathrm{sg}$ person of a vrea, with impersonal meaning) + subjunctive (example $26)^{23}$ one may form future in the past by using the imperfect of the verb a vrea $(27,28)$ :

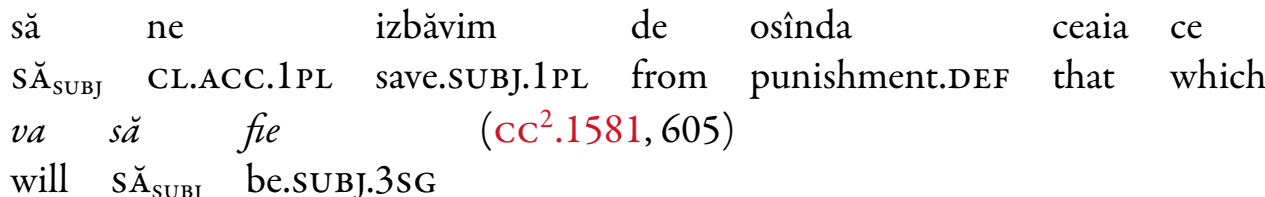

'let's save ourselves from the punishment that will be'

(27) incepu lor a grăi ce vrea lui

start.Ps.3sG them.DAT $\mathrm{A}_{\mathrm{INF}}$ speak.INF what AUX.3sG him

$s \breve{a} \quad f i e, \quad$ că "iată, ieșim întru Ierusalim,

S $\breve{A}_{\text {SUBJ }}$ be.SUBJ.3SG that behold go.out.1PL in Jerusalem

și fiiul omenesc vîndut va $f i$ mai-marilor preuți

and son.DEF human sold will be.INF bigger.DEF priests.DAT

și cărtularilor” $\quad\left(\mathrm{CC}^{2} .1581,87\right)[M k, 10,33]$

and scribes.DEF.DAT

'he started to speak to them about what would happen to him, that "Behold, we are going up to Jerusalem, and the Son of Man will be delivered over to the chief priests and the scribes"'

(28) Întîi spuse Hristos ucenicilor săi ce

first say.Ps.3sg Christ disciples.DEF.DAT his what

vrea să fie lui $\left(\mathrm{CC}^{2} .1581,90\right)$

AUX.3G SĂ $\breve{\text { SUBJ }}$ be.SUBJ.3SG him.DAT

'First said Christ to his disciples what would happen to him'

The Aromanian periphrasis, made up of the invariable form vrea (the imperfect $3 \mathrm{sg}$ of the verb a vrea) + the present subjunctive (vrea s-aflu 'I will find out') (Saramandu, 1984, p. 459; Nevaci, 2006, p. 145146; Nevaci \& Todi, 2009), represents the same construction pattern. The main difference between the

\footnotetext{
${ }^{23}$ This type of future has developed in Daco-Romanian in the construction containing an invariable particle $o$ (or partially invariable: $o / o r)$ : o să vină 'will come'.
} 
perihrasis vrea să facă/vrea s-facu 'I will do' in old Romanian and in Aromanian and the type vrea face consists in the replacement of the infinitive through the subjunctive, as a consequence of the Balkanic tendency to eliminate the infinitive, which has generalized in Aromanian.

\section{The similar paradigms in the dialect of Banat and in Istro-Romanian}

In support of the *volere hypothesis, Weigand (1896) has brought forth the arguments regarding the similarities with the periphrases in Istro-Romanian and the dialect of Banat, where the connection between the auxiliary and the verb a vrea is obvious.

The auxiliary forms in Istro-Romanian are:

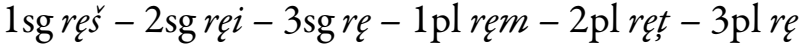

$$
\begin{aligned}
& \text { (Philippide, 1927, II, p. 194-201; Kovačec, 1971, p. 148; 1984, p. 577) }
\end{aligned}
$$

Philippide (1927, p. 194-201) also records other phonetic variants which may represent approximations of transcription in the utilised corpus: 1 sg raš, re; $2 \mathrm{sg}$ rai, rei; $1 \mathrm{pl} \mathrm{ręn,} \mathrm{ren} \mathrm{etc.} \mathrm{(cf.} \mathrm{also} \mathrm{Sârbu} \mathrm{\&} \mathrm{Frăţilă,}$ 1998, p. 26).

The forms of the Istro-Romanian auxiliary may be very easily explained through the apheresis of the initial $v$-, and appear as an intermediary link between a paradigm of the verb a vrea 'want' and the even shorter forms of the auxiliary in Daco-Romanian.

The dialect of Banat has similar forms:

$$
\begin{aligned}
& \text { 1sg reaș }-2 \text { sg reai }-3 \text { sg rea }-1 \mathrm{pl} \text { ream }-2 \mathrm{pl} \mathrm{reați}-3 \mathrm{pl} \text { rea } \\
& \text { (Neagoe, 1984, p. 264) }
\end{aligned}
$$

The forms in the dialect of Banat are attested since the end of the $18^{\text {th }}$ century by Paul Iorgovici, who-in a book dedicated to the literary language-constantly uses the present and the perfect conditional:

(29)

$$
\begin{array}{llll}
\text { Multe exempluri se } & \text { reau } & \text { putea aduce } \\
\text { many examples CL.REFL.PASs.3sG } & \text { AUX.3PL can.INF } & \text { bring.INF } \\
\text { (Iorgovici.1799, 137) } & & & \\
\text { 'Many examples could be brought' } & & &
\end{array}
$$

(30) de le ream fi cunoscut, ream zice

if CL.ACC.F.PL AUX.1PL be.INF know.PPLE AUX.1PL say.INF

(Iorgovici.1799, 147)

'Had we known them, we would have said'

A difference between the forms used by Iorgovici and the ones recorded later in the dialect is the $-u$ ending for $3 \mathrm{pl}$-an innovation of the dialect of Banat involving the forms of the imperfect, attested since the $16^{\text {th }}$ century (Gheție, 1994, p. 124) and taken over in the literary language. The presence of the ending would indicate the fact that the auxiliary was still associated to the imperfect wherefrom it had sprung ${ }^{24}$.

The forms in Istro-Romanian and the dialect of Banat have the value of a non-counterfactual hypothetical in the first place and correspond very well, both formally and semantically, to the present conditional of the type aş + infinitive (kept almost unchanged since the $16^{\text {th }}$ century until the present day).

The connexion of this series of forms with that of the auxiliary as, ai, are, etc. has been explained by the opponents of the *volere theory as late influence arrived at through contamination between the auxiliary vrea (the pattern discussed in $\$ 4.1$ ) and the aş-series. It is, however, plausible that Istro-Romanian and the

\footnotetext{
${ }^{24}$ One must, however, specify that reau seems to be the only form of $3^{\text {rd }}$ person-sg and pl.- in the text (reau sta cineva, Iorgovici.1799, p. 247).
} 
dialect in Banat might have simply kept intermediary phases of the shortening of the auxiliary. The only forms that cannot be explained through the presence/absence of the re-segment are those in the $3 \mathrm{sg}$ and pl: ară / are / ar vs. rea / reau.

The perfect conditional is a periphrasis which contains an extra element marked as 'perfect': the dialect of Banat features the same structure as the one used for the standard perfect conditional (am ficunoscut '(we) would have known'): ream fi cunoscut [example (30), supra]. The situations signalled in Neagoe (1984, p. 264) as archaic periphrases of the perfect conditional —of the type vream cinta (1sg) - seem to be examples of the future in the past in which the auxiliary has received the more recent endings of the imperfect. In Istro-Romanian the perfect is formed differently: with the participle of $a f i$, and the lexical verb in the infinitive (rę̌s fost cânta, Kovačec, 1984, p. 577).

\section{The morphological hypothesis}

Two of the auxiliary forms have posed difficulties when it comes to explaining their origin: $1 \mathrm{sg}$ ass and $3 \mathrm{sg}$ and $\mathrm{pl}$ ară/are/ar. The other forms can easily be accounted for by starting from the imperfect VOLEBAM, which, through phonological development, gave rise to the series (attested in the $16^{\text {th }}$ century):

$$
1 \text { sg vrea }-2 \text { sg vreai }-3 \mathrm{sg}=3 \mathrm{pl} \text { vrea }-1 \mathrm{pl} \text { vream }-2 \mathrm{pl} \text { vreat } i^{25}
$$

With respect to aş, Philippide (1894, p. 70) has proposed an explanation in the particle și $<$ sIC, which would have been added at the end of the verb with a deictic and intensifying role. Adopted by others, this idea has nevertheless failed to convince in the absence of similar developments suggesting a regular pattern. Rosetti (1978) supposed that aş had originated from the past perfect of the conjunctive in Latin of the verb HABERE-HABUISSEM.

A more credible explanation is an account regarding the appearance of the ending $-s$, by analogy with the 1sg ending of some strong etymological simple past forms (ziş(i) 'I said', duş(i) 'I carried', merș(i) 'I went', spuş(i) 'I said', etc.). Tiktin (1904) has hypothesised that this analogic $-s$, in the paradigm derives from the verb HABERE; Bugeanu (1970) considered that the analogic ending was added for differentiation reasons to some forms which also derived from the simple past of HABERE. Frâncu (2009, p. 121) suggests that the analogic ending was added to the imperfect of the mixed paradigm VOLEBAM/HABEBAM.

For ară/are/ar, the phonetic evolution has been reconstructed in several ways. The supporters of the HABERE hypothesis (with the present form) have considered that the ară form reflects the strong pronunciation of $r$, while are and ar are the natural results of phonetic evolution ${ }^{26}$. In the ${ }^{*}$ volere hypothesis, it is assumed that the forms of $3 \mathrm{sg}$ and $3 \mathrm{pl}$ are arrived at through regular eliminations of sounds, through the modification in the pronunciation of the sonorant $r$ or through metathesis:

(a) * volebat $>$ reare $>$ are $>$ ar (Arvinte, 2004, p. LI)

(b) VOLEBAT $>$ *voare $>$ vare $>$ are; ară through velarizing $e$ after $r$; ar by dropping the final vowel (Frâncu, 2009, p. 121-122)

The auxiliary paradigm may, however, be accounted for by way of the contamination between the paradigms of the imperfect and the simple past of ${ }^{*}$ volere/vrea ${ }^{27}$. As the process of forming the conditional dates probably later than common Romanian as the same construction cannot be found in the dialects spoken to the South of the Danube (Caragiu-Marioțeanu, 1969, p. 272), there is no need to seek recourse in the remote Latin etymon, as the explanation could start either from the reconstructed variants for old Romanian or from the variants which are attested in the first texts. Romanian would be closer to Italian in this respect, where the conditional auxiliary comes from the Latin perfect (Meyer-Lübke, 1895; Rohlfs, 1968). The contamination could be formally accounted for through the necessity of marking person (the

\footnotetext{
${ }^{25}$ See Densusianu (1975, p. 701), with the exception of the form for $2 \mathrm{pl}$.

${ }^{26}$ Actually, the form are in the present of the verb a avea 'to have' is also obscure.

${ }^{27}$ The verb a vrea also has other attested contaminations of paradigms (e.g., the modern imperfect vroiam).
} 
Rodica Zafiu

imperfect having too many syncretisms) and it would be semantically acceptable within the perspective of cross-linguistic comparison due to the fact that both the imperfect as well as the perfect (i.e. simple past) could become a source of the counterfactual meaning. The fact that it is only the periphrases for the simple past which are absent from the series where the form of the verb a vrea is completely preserved (see supra, \$4.) would support this explanation, if we suppose that in the speakers' consciousness aş + infinitive was still connected to the simple past (and this is why it could be used as a narrative tense in the old translations). If it were so, we would no longer speak of vrea + infinitive sequence in terms of a residue or a reconstruction, but in terms of a paradigm (a vrea in the past + infinitive) which is only related to ar + infinitive.

In the $16^{\text {th }}$ century, the simple past forms of a vrea were (Zamfir, 2007, p. 94):

vrui, vruşi, vru, vrum, vrut, vrură

In order to obtain the result attested in the $16^{\text {th }}$ century as the paradigm of the conditional auxiliary, we need to assume an analogic ending for the 1st person sg., a form vruş(i), homonymous to the current 2 sg form, as well as an extension of the ending $r a \breve{a}$ from $3 \mathrm{pl}$ to $3 \mathrm{sg}$. Both extensions rely on syncretisms existing in various areas of the Romanian verbal system $(1 \equiv 2 \mathrm{sg}, 3 \mathrm{sg} \equiv \mathrm{pl})$.

Hence, at the origin of the current forms of the auxiliary and of the variants in Istro-Romanian and the dialect of Banat may lay the contamination of the paradigm of the imperfect with the one for the simple past in $1 \mathrm{sg}$, 3sg and $3 \mathrm{pl}$ :

\begin{tabular}{|c|c|c|}
\hline vrea / vruş & $\rightarrow$ & (vr)eaş / reaş / (vr)aş > aş \\
\hline vreai & $\rightarrow$ & (vr)eai / reai / (vr)ai > ai \\
\hline vrea / vru+ră & $\rightarrow$ & (vr)eară / reară / (vr)ară $>$ ară \\
\hline eam & $\rightarrow$ & (vr)eam / ream, \\
\hline reați & $\rightarrow$ & (vr)eați/reați / (vr)ați > ați \\
\hline ea / vrură & $\rightarrow$ & (vr)eară / reară / (vr)ară $>a$ \\
\hline
\end{tabular}

The contamination between the forms of the simple past and of the imperfect also occurred in some Italian dialects; the facts are mentioned by Meyer-Lübke (1895, p. 402) ${ }^{28}$ and described by Rohlfs (1968, p. 344345).

The variants in which it is just the initial $v$ - which gets removed correspond to the forms existing in the inversions in old Romanian as well as in those retained in Istro-Romanian and the dialect of Banat. One example dating from the $16^{\text {th }}$ century (and extensively discussed by Zamfir, 2007, p. 333, who considers it "a strange form") may be interpreted as an instance of retention of a longer form of the auxiliary in the context of the homonymy between the initial dropped consonant and the form of the pronominal $\mathrm{clitic}^{29}$ :

(31) de-ați fi fost den lume fiind, lumea if $=$ AUX.2PL be.INF be.PPLE of world be.GER world.DEF

\footnotetext{
28 "Dans les patois du Nord comme du Sud, les uns employaient jadis, les autres connaissent encore une flexion mélangée, c-à-d. qu'ils ont fait choix de l'imparf. pour les $1^{\text {re }}$ et $3^{\mathrm{e}}$ p. sing. e $3^{\mathrm{e}}$ plur., du parfait pour les autres formes: de là $-i a,-e s t i,-i a$, -emmo,-este, -iano" [In the Northern patois as well as in the Southern ones, some of them used a long time ago, while others still evince a mixed inflection, i.e., they selected the imperfect for $1^{\text {st }}$ and $3^{\text {rd }}$ person singular and $3^{\text {rd }}$ person plural, the perfect for the other forms: hence -ia, -esti, -ia, -emmo, -este, -iano] (Meyer-Lübke, 1895, p. 402). Surprisingly, the pattern of the blending of forms is identical with the one we propose for Romanian, but has the inverse distribution: $1 \mathrm{sg}$, 3sg and 3pl person forms would come from the perfect.

${ }^{29}$ The editors transcribe the sequence vreară (the image is reproduced in Appendix A), but the context clearly requires the identification of the initial $v$ - as belonging to the 2 pl clitic. In the evangelical translation from CT.1560-1, the conditional construction includes the pronominal clitic and the conditional periphrasis without the participle (the present conditional), with reversed auxiliary: "De ațifi fostŭ den lume, lumea amu a sa iubi-v-ară" [If you had been from this world, this world would love you as its own] (CT.1560-1,221 $\left.{ }^{\mathrm{v}}\right)$.
} 
v-reară $\quad f i \quad$ iubit $\quad\left(\mathrm{CC}^{2} .1581,522,524\right)[J n, 15,19]$

CL.ACC.2PL=AUX.3SG be.INF love.PPLE

'If you had been from the world, the world would have loved you' (The standard version: 'If you were of the world, the world would love you')

The form occurs twice: in the evangelic text (which contains, as known, an older level of language than in the homiletic commentary) and in its fragmentary resumption, in explanations. Identical repetition renders this isolated attestation a little less contestable such that it may not be reduced to a mere writing mistake.

\section{Conclusions}

In order to account for the formation of the Romanian conditional, we propose the following path: similarly to the grammaticalization of the simple future formed with the aid of the infinitive and the present of the verb a vrea, another grammaticalization process took place involving a periphrasis of the future in the past, built with the infinitive together with a mixed paradigm obtained by way of contamination between the forms of simple past and imperfect of the verb a vrea (vreaş, vreai, vreară, vream, vreați, vreară). The future in the past (the association between uncertain posteriority and past) lays, as in many other languages, at the heart of the development of a hypothetical counterfactual meaning. Often used in postposition (during a period of time when the future and the conditional auxiliaries of the Western Romance languages got fixed in this position to the point that they even became inflexions), the auxiliary forms underwent an abbreviation process through phonetic simplification and as a consequence of the reinterpretation of the segment $r e-$ as belonging to the infinitive. The short forms aş, ai, ară, am, ați, ară partially lost their connection with the verb a vrea, which accelerated their specialization as markers of the conditional ${ }^{30}$. However, they still preserved a temporal meaning for a while (in the $16^{\text {th }}$ century), sometimes occurring in the contexts of the simple past as future in the past. The hypothetical value split in a hypothetical about present and future (aş face 'I would do') and a hypothetical referring to the past, due to the emergence of a periphrasis with the participle: aş face 'I would do' vs. aş fi faccut 'I would have done'.

Other similar constructions containing the verb a vrea in the imperfect and the compound past have had a slower pace of grammaticalization (or the process itself started at a later time). In the $16^{\text {th }}$ century the periphrasis built with the imperfect of the verb a vrea (vrea, vreai, vrea, vream, vreați, vrea + infinitive) is especially widespread. Its main values are those of future in the past and of hypothesis referring to the present. Besides this, a periphrasis with a doubly-marked temporality, specialized for the counterfactual past hypothetical (vrea fi fäcut 'would have done') was created. The variants for the future in the past and the conditional are retained: as face as a standard form, reas face in Istro-Romanian, the dialect of Banat and in other areas (in isolation), vrea face in some Northern patois.

The explanation resting on the past forms of the verb *volere/vrea is the only one that can lend coherence to the data, due to the fact that it integrates them within a unitary and visible grammaticalization process manifested in many other languages. The semantic objections which have been raised against it are irrelevant because they do not take into account the typical formation process of a mood expressing the hypothetical condition. In this process, the passage from the temporal-modal value to the modal oneof counterfactual and non-counterfactual hypothetical meaning-is normal and frequently attested. The retention of some residues from the old temporal value or the use of these forms in hypothetical contexts

\footnotetext{
${ }^{30}$ One may draw an analogy with the future of the type $v o i+$ infinitive: this future starts alternating with the syntactically identical periphrasis with an auxiliary undergoing apheresis: $o i+$ infinitive. The modal and evidential values ("the presumptive mood") occur in both forms but the form $o i+$ infinitive gets specialized for evidentiality in time. A similar process may have taken place with the periphrasis vreaş + infinitive, at the time when it started co-varying with the periphrasis undergoing apheresis * (e)aş + infinitive: the latter, given it obscured etymological connections, entered an accelerated process of specialization for the conditional value. Both forms continued to circulate, however.
} 
of present vs. past do not contradict their relatedness, because they belong to the same process, at different stages. The objections regarding the form may be rejected by presupposing a contamination between the paradigm of the simple past and of the imperfect. The periphrases with a vrea in the language of the first texts and in Aromanian confirm the productivity of the pattern, and the forms in the dialect of Banat and in Istro-Romanian are simply variants of a common grammaticalization process with internal variations and different rhythms. Some of these variants were abandoned in time on account of the equivalence and the competition between them.

\section{Bibliography}

\section{A. Corpus}

A.1620 = Alexandria, în Zgraon, Fl. (ed.), Cele mai vechi cărți populare în literatura română, vol. 11, Fundaţia Naţională pentru Știință și Artă, București, 2006.

вв.1688 = Biblia adecă Dumnezeiasca Scriptură a Vechiului şi Noului Testament, tipărită întîia oară la 1688 în timpul lui Șerban Vodă Cantacuzino, Domnul Țării Românești, Editura Institutului Biblic, București, 1977.

$\mathrm{CC}^{1} .1567=$ Coresi, Tîlcul evangheliilor și molitvenic românesc, ed. V. Drimba, Editura Academiei, București, 1998.

$\mathrm{CC}^{2} .1581$ = Coresi, Cartea cu invvățătură (1581), vol. I, Textul, ed. S. Pușcariu \& Al. Procopovici, Atelierele Grafice Socec, București, 1914.

CPr.1566 = Texte de limbă din secolul XVI, IV. Lucrul apostolesc tipărit de diaconul Coresi la 1563, ed. I. Bianu, Cultura Națională, București, 1930.

ст.1560-1 = Coresi, Tetraevanghelul tipărit de Coresi, Brașov 1560-1561, comparat cu Evangheliarul lui Radu de la Mănicești. 1574, ed. Fl. Dimitrescu, Editura Academiei, București, 1963.

Cv.1563-83 = Codicele Voronețean, ed. M. Costinescu, Editura Academiei, București, 1981.

Diaconovici Loga.1822 = C. Diaconovici Loga, Gramatica românească (Buda, 1822), ed. O. Șerban \& E. Dorcescu, Editura Facla, Timișoara, 1973.

Iorgovici.1799 = P. Iorgovici, Observații de limba rumânească, ed. D. Bogdan Dascălu \& C. Dascălu, Editura Facla, Timișoara, 1979.

Mărg.1691 = Ioan Gură de Aur, Mărgăritare, ed. R. Popescu, Editura Libra, București, 2001.

MI 1620 = Manuscrisul de la Ieud, ed. M. Teodorescu \& I. Gheție, Editura Academiei R.S.R., Bucureşti, 1977.

NT.1648 = Noul Testament, Editura Reîntregirea, Alba Iulia, 1998.

PH.1500-10 = Psaltirea Hurmuzaki, ed. I. Gheție \& M. Teodorescu, Editura Academiei Române, București, 2005.

po.1582 = Palia de la Orăștie, I. Textul, ed. V. Arvinte, I. Caproșu \& Al. Gafton, Editura Universității „Alexandru Ioan Cuza”, Iași, 2005.

Prav.1646 = Carte românească de invățătură, 1646, ed. A. Rădulescu, Editura Academiei, București, 1961.

Prav.1652 = Îndreptarea legii, 1652, ed. A. Rădulescu, Editura Academiei, București, 1962.

SA.1683 = Ioan Zoba din Vinț, Sicriul de aur, ed. A. Goția, Editura Minerva, București, 1984.

\section{B. References}

Arvinte, V. (2004). Normele limbii literare in Biblia de la București (1688), Editura Universității „Alexandru Ioan Cuza”, Iași. Arvinte, V. (2007). Normele limbii literare in Palia de la Orăștie, in Gafton, Al. \& Arvinte, V., Palia de la Orăștie (1582), II. Studii, Editura Universității „Alexandru Ioan Cuza”, Iași, p. 259-412.

Azzopardi, S. (2013). Valor aspecto-temporal y usos modales del condicional a la luz de la noción de gramaticalización, in Cabedo Nebot, A., Aguilar Ruiz, M. \& López-Navarro Vidal, E. (eds), Estudios de Lingüistica: investigaciones, propuestas y aplicaciones, Tecnolingüística, Valencia, p. 337-347, [online].

Bugeanu, D. (1970). Formarea condiționalului în limba română, in "Studii și cercetări lingvistice", vol. XXI, nr. 5, p. 543-563.

Bybee, J.L. (1995). The semantic development of past tense modals in English, in Bybee, J.L. \& Fleischman, S. (eds), Modality in Grammar and Discourse, John Benjamins, Amsterdam, p. 503-517, Crossref.

Bybee, J.L., Perkins, R. \& Pagliuca, W. (1994). The Evolution of Grammar, University of Chicago Press, Chicago / London.

Capidan, T. (1932). Aromânii. Dialectul aromân, Imprimeria Națională, București.

Caragiu-Marioțeanu, M. (1969). Verbul, in Rosetti, Al. (coord.), Istoria limbii române, II, Editura Academiei R.S.R, București, p. 254-278.

Călărașu, C. (1987). Timp, mod, aspect in limba română in secolele al XV-lea - al XVIII-lea, Tipografia Universităţii din București, București.

Coene, M., Tasmowski, L. (2006). On the Balkan-Slavic origins of the Romanian conditional, in "Revue roumaine de linguistique", vol. LI, nr. 2, p. 321-340.

Densusianu, O. (1975). Opere, II. Histoire de la langue roumaine, ed. B. Cazacu, V. Rusu, I. Șerb, Editura Minerva, București; ed. I: $1901-1938$. 
Dragomirescu, A. (2015). Verbul, in Chivu, Gh. et al. (eds), Studii de istorie a limbii române. Morfosintaxa limbii literare în secolele al XIX-lea și al XX-lea, ed. revăzută și adăugită, Editura Academiei Române, București, p. 185-222.

D'Hulst, Y., Coene, M. \& Avram, L. (2004). Syncretic and Analytic Tenses in Romanian. The Balkan Setting of Romance, in Mišeska Tomić, O. (ed.), Balkan Syntax and Semantics, John Benjamins, Amsterdam, p. 355-374, Crossref.

Elson, M. (1992). A Latin Source for the Conditional Auxiliary in Romanian, in "Zeitschrift für Romanische Philologie", vol. 108, nr. 5-6, p. 360-375, Crossref.

Esher, L. (2013). Future and conditional in Occitan: a non-canonical morphome, in Cruschina, S., Maiden, M. \& Smith, J.C. (eds), The Boundaries of Pure Morphology. Diachronic and Synchronic Perspectives, Oxford University Press, Oxford, p. 95115, Crossref.

Fleischman, S. (1982). The Future in Thought in Language. Diachronic Evidence from Romance, Cambridge University Press, Cambridge.

Frâncu, C. (1983-1984). Geneza și evoluția timpurilor verbale supracompuse în limba română, in "Anuar de lingvistică și istorie literară", vol. XXIX, p. 23-62.

Frâncu, C. (2009). Gramatica limbii române vechi (1521-1780), Casa Editorială Demiurg, Iași.

Gheție, I. (1994). Introducere în dialectologia istorică românească, Editura Academiei Române, București.

Giannakidou, A. \& Mari, A. (2017). A unified analysis of the future as epistemic modality: The view from Greek and Italian, in "Natural Language and Linguistic Theory", Crossref.

Hasdeu, B. P. (1892). Etymologicum magnum Romanie, II, Editura Socec, București.

Heine, B. \& Kuteva, T. (2002). World Lexicon of Grammaticalization, Cambridge University Press, Cambridge, Crossref.

Iatridou, S. (2000). The Grammatical Ingredients of Counterfactuality, in "Linguistic Inquiry", vol. 31, nr. 2, p. 231-270, Crossref.

Iordan, I. (1928). Dialectele italiene de sud și limba română. V. Sintactice, in "Arhiva”, vol. 35, nr. 3-4, p. 181-204.

James, D. (1982). Past tense and the hypothetical. A cross-linguistic study, in "Studies in Language", vol. 6, nr. 3, p. 375-403, Crossref.

Ivănescu, G. (2000). Istoria limbii române, ed. a II-a, Editura Junimea, Iași.

Kovačec, A. (1971). Descrierea istroromânei actuale, Editura Academiei R.S.R., București.

Kovačec, A. (1984). Istroromâna, in Rusu, V. (ed.), Tratat de dialectologie românească, Editura Scrisul Românesc, Craiova, p. 550-590.

Lombard, A. (1954-1955). Le verbe roumain. Étude morphologique, I-II, C. W. K. Gleerup, Lund.

Meyer-Lübke, W. (1895). Grammaire des langues romanes, II. Morphologie, Welter, Paris.

Meyer-Lübke, W. (1900). Grammaire des langues romanes, III. Syntaxe, Welter, Paris.

Minuț, A.-M. (2002). Morfosintaxa verbului în limba română veche, Editura Universității „Alexandru Ioan Cuza”, Iași.

Morariu, L. (1925). Morfologia verbului predicativ român, I, in "Codrul Cosminului. Buletinul «Institutului de Istorie ş,i Limbă »", vol. 1 (1924), p. 1-95.

Neagoe, V. (1984). Subdialectul bănățean, in Rusu, V. (ed.), Tratat de dialectologie românească, Editura Scrisul Românesc, Craiova, p. 240-283.

Nevaci, M. (2006). Verbul în aromână. Structură și valori, Editura Academiei Române, București.

Nevaci, M., Todi, A. (2009). The Grammaticalization of Perfect Auxiliaries in Romanian. Historical and Dialectal Aspects, in "Revue roumaine de linguistique", vol. LIV, nr. 1-2, p. 137-150.

Pamfil, C.-G. \& Dănilă, E. (2009). Originea condițional-optativului românesc în concepția lui A. Philippide, in "Philologica Jassyensia”, vol. V, nr. 1, p. 69-77.

Papahagi, T. (1925). Graiul și folklorul Maramureșului, Cultura Națională, București.

Parkinson, J. (2009). A Diachronic Study into the Distributions of Two Italo-Romance Synthetic Conditional Forms, Ph.D. thesis, University of St. Andrews, [online].

Philippide, A. (1888). Introducere în studiul limbei și literaturei române, Editura Librăriei Frații Șaraga, Iași.

Philippide, A. (1894). Principii de istoria limbii, Editura Librăriei Frații Șaraga, Iași.

Philippide, A. (1927). Originea românilor, II. Ce spun limbile romînă și albaneză, Tipografia Viața Românească, Iași.

Philippide, A. (2011). Istoria limbii române, ed. de G. Ivănescu, C.-G. Pamfil și L. Botoșineanu, Polirom, Iași.

Popescu, C.M. (2013). Viitorul și condiționalul în limbile romanice. Abordare morfosintactică și categorizare semantică din perspectivă diacronică, Editura Universitaria, Craiova.

Popescu, M. (2014). 'Viitorul în trecut' în limba română contemporană. Un punct de vedere semantico-pragmatic, in "Revista de Filología Románica”, vol. 31, nr. 1, p. 111-125, Crossref.

Rohlfs, G. (1968). Grammatica storica della lingua italiana e dei suoi dialetti, II. Morfologia, Einaudi, Torino.

Rosetti, A. (1932). Limba română în secolul al XVI-lea, Cartea Românească, București.

Rosetti, A. (1978). Istoria limbii române. De la origini până în secolul al XVII-lea, ed. a II-a, Editura Științifică și Enciclopedică, București.

Saramandu, N. (1984). Aromâna, in Rusu, V. (ed.), Tratat de dialectologie românească, Editura Scrisul Românesc, Craiova, p. $432-476$.

Sârbu, R. \& Frățilă, V. (1998). Dialectul istroromân. Texte și glosar, Editura Amarcord, Timișoara. 
Theodorescu, M. (1978). Condiționalul, in Dimitrescu, F. (ed.), Istoria limbii române. Fonetică. Morfosintaxă. Lexic, Editura Didactică și Pedagogică, București, p. 320-322.

Thieroff, R. (2010). Moods, Moods, Moods, in Rothstein, B. \& Thieroff, R. (eds), Mood in the Languages of Europe, John Benjamins, Amsterdam / Philadelphia, p. 1-29, Crossref.

Tiktin, H. (1904). Die Bildung des rumänischen Konditionalis, in “Zeitschrift für romanische Philologie”, vol. 28, nr. 6, p. 691704, Crossref.

Titova, V.P. (1959). O problemă litigioasă a morfologiei istorice românești (originea condiționalului), in "Studii și cercetări lingvistice", vol. X, nr. 4, p. 561-571.

Vincent, N. (2013). Compositionality and change in conditionals and counterfactuals in Romance, in Cruschina, S., Maiden, M. \& Smith, J.C. (eds), The Boundaries of Pure Morphology. Diachronic and Synchronic Perspectives, Oxford University Press, Oxford, p. 116-136, Crossref.

Weigand, G. (1896). Die Bildung des Imperfecti Futuri-Konditionalis, Optativi-im Rumänischen, in "Jahresbericht des Instituts für Rumänische Sprache”, vol. III, p. 139-161.

Zafiu, R. (2013). Mood, tense, and aspect, in Pană Dindelegan, G. (ed.), The Grammar of Romanian, Oxford University Press, Oxford, p. 24-65.

Zafiu, R. (2016). The syntax of moods and tenses, in Pană Dindelegan, G. (ed.), The Syntax of Old Romanian, Oxford University Press, Oxford, p. 14-52, Crossref.

Zamfir, D.-M. (2007). Morfologia verbului în dacoromâna veche (secolele al XVI-lea-al XVII-lea), II, Editura Academiei Române, București.

\section{Appendix A.}

